\title{
Connected in Print: Selecciones del Reader's Digest, U.S. Cultural Relations, and the Construction of a Global Middle Class*
}

\section{Lisa Ubelaker Andrade ${ }^{1}$}

Recibido: 01/03/2019

Aprobado por pares: 08/06/2019
Enviado a pares: $10 / 03 / 2019$

Aceptado: 08/06/2019

DOI: 10.5294/pacla.2019.22.4.7

To reference this paper / para citar este artículo / para citar este artigo

Ubelaker Andrade, L. (2019). Connected in print: Selecciones del Reader's Digest, U.S. cultural relations, and the construction of a global middle class. Palabra Clave, 22(4), e2247. DOI: https://doi.org/10.5294/pacla.2019.22.4.7

\section{Abstract}

This article traces the early history of the Reader's Digest's global editions, and in particular its Latin American magazine, Selecciones del Reader's Digest, viewing this popularly consumed text as a window into transnational government and media initiatives to forge a "global middle class." It contends that the magazine, rather than merely idealizing life in the United States, asserted that readers could use media to join an imagined community of likeminded "professionals" and "free peoples" around the world. Using documents from the U.S. National Archives, the magazine, as well as a variety of other press sources, the paper untangles the connections between the first truly-global U.S. consumer magazine and the U.S. geopolitical project. First, it describes the relationship between the launch of Reader's Digest's Latin American edition and the U.S. cultural campaign's wartime initiatives; second, it examines the magazine's content, illustrating how the notion of a global

* This article stems from the authors dissertation research (though she wrote the article independent from the dissertation), which was financed by the Social Science Research Council, Mellon Mays Foundation, and Fulbright.

1 https://orcid.org/0000-0002-3841-1855. Universidad de San Andrés, Argentina. lubelaker@udesa.edu.ar 
connection was depicted in its pages. Taken together, these sections illustrate how the transnational mass media not only normalized the notion of a righteous middle class but also narrated that group's globality, seeking to implicate the reader in its scope.

\section{Keywords (Source: Unesco Thesaurus)}

Mass media; mass culture; transnational media; middle class; Reader's Digest; U.S. cultural diplomacy. 


\section{Conectados en imprenta: Selecciones del Reader's Digest, relaciones culturales de Estados Unidos y la construcción de una clase media global}

\section{Resumen}

Este artículo hace un recorrido por los orígenes de las ediciones globales de Reader's Digest y, de manera particular, de su popular versión latinoamericana, Selecciones del Reader's Digest, que se considera como una ventana hacia el gobierno transnacional y las iniciativas de los medios para forjar una "clase media global". Se sostiene que la revista, en vez de simplemente idealizar la vida en Estados Unidos, afirma que los lectores podrían usar los medios para unirse a una comunidad imaginada de "profesionales" y "personas libres" con ideas similares en todo el mundo. Por medio de documentos de los Archivos Nacionales de Estados Unidos, la revista y una variedad de otras fuentes de prensa, se desenmarañan las conexiones existentes entre la primera revista estadounidense de consumo verdaderamente global y el proyecto geopolítico de Estados Unidos. En primer lugar, se describe la relación entre el lanzamiento de la edición latinoamericana de Reader's Digest y las iniciativas de la campaña cultural de Estados Unidos durante la Segunda Guerra Mundial; en segundo lugar, se examina el contenido de la revista, ilustrando la manera en que se representaba la noción de una conexión global en sus páginas. En conjunto, estas secciones muestran cómo los medios de comunicación transnacionales no solo normalizaron la noción de una clase media justa, sino que también narraron la globalidad de ese grupo, buscando involucrar al lector en el alcance del mismo.

\section{Palabras clave (Fuente: Unesco Thesaurus)}

Medios de comunicación; cultura de masas; medios transnacionales; clase media; Reader's Digest; diplomacia cultural de EE.UU. 


\section{Conectados em publicação: Seleções do Reader's Digest, relações culturais dos Estados Unidos e a construção de uma classe média global}

\section{Resumo}

Este artigo traça as origens das edições globais de Reader's Digest e, em particular, sua popular versão latino-americana, Seleções do Reader's Digest, considerada uma janela para o governo transnacional e as iniciativas da mídia para criar uma "classe média global". Argumenta-se que a revista, em vez de simplesmente idealizar a vida nos Estados Unidos, afirma que os leitores poderiam usar a mídia para ingressar em uma comunidade imaginada de "profissionais" e "pessoas livres" com ideias semelhantes a nível mundial. Por meio de documentos dos Arquivos Nacionais dos Estados Unidos, da revista e de várias outras fontes de imprensa, são reveladas as conexões entre a primeira revista americana de consumo verdadeiramente global e o projeto geopolítico dos Estados Unidos. Em primeiro lugar, descrevem-se a relação entre o lançamento da edição latino-americana do Reader's Digest e as iniciativas da campanha cultural dos EUA durante a segunda guerra mundial; em segundo lugar, examina-se o conteúdo da revista, ilustrando como a noção de conexão global foi representada em suas páginas. Juntas, essas seções mostram como a mídia transnacional não apenas normalizou a noção de uma classe média justa, mas também narraram a globalidade desse grupo, buscando envolver o leitor em seu escopo.

\section{Palavras-chave (Fonte: Unesco Thesaurus)}

Mídia; cultura de massa; mídia transnacional; classe média; Reader’s Digest; diplomacia cultural dos Estados Unidos. 
In August of 1940, Reader's Digest magazine extended a peculiar request to its subscribers: Would they join a campaign to bring the peoples of North and South America "closer together"? Editors announced plans to launch the first ever foreign-language edition, a monthly magazine designed specifically for Latin American audiences, in Spanish. With the donation of a single dollar, readers from the United States (U.S.) could sponsor a yearlong subscription for a Latin American with "a similar occupational interest" to their own. If the donor did not specify who should receive the subscription, the company would choose from "a list of Latin American doctors, lawyers, businessmen, students, and prominent women, and others" ("Reader's Digest, Spanish," 1940, p. 9) to receive the magazine.

The suggestion that U.S. individuals should engage in paternalistic aid to help "similar" persons in Latin America obtain their favorite magazine occurred amid a particular moment in U.S. cultural relations. By 1940, concerns that Axis forces might attack the United States by first gaining a stronghold in Latin America became a subject of concern for many Americans. Over the following several years, the United States government strengthened its investment in the region, and, through the Office of the Coordinator of Inter-American Affairs (OCIAA), under the direction of Nelson Rockefeller, produced media designed to curb Nazi influence and advance U.S. shares of the consumer market (Cramer \& Prutsch, 2012; Hart, 2013). The office also provided incentives for private entities willing to invest in pro-Allied propaganda aimed at the region. Everyday Americans began to participate in these efforts, apparently eager to imbue the country's Good Neighbor policy with local action. The launch of Selecciones-a privately controlled venture that was eventually emboldened by collaboration with the OCIAA- exemplified the era's new cultural diplomacy: the private project was billed as a way to build cultural ties outside of the United States while also contributing to international diplomacy; press surrounding the venture stated that the Latin American edition of the U.S. magazine would aid the U.S. war effort, consolidating support for the United States in the region.

Adding to its significance was the fact that, unlike the vast majority of OCIAA media projects, Selecciones was a commercial success. Early company 
predictions estimated that, during its first years of production, the magazine would reach a maximum circulation of 25,000 copies per month. Early subscriptions, however, exceeded this number. When the first issues went for public sale, local vendors sold 225,000 copies of Selecciones across Spanish-speaking Latin America ("Sets Circulation Record," 1940, p. 17). In one year, Argentines alone bought 155,000 copies of the magazine per month and the company estimated that it reached more than 400,000 readers in the country. In Lima, vendors reported that copies of Selecciones were gone two days after the magazine's delivery and in Havana, the first allotment of 18,000 copies sold out within hours (Cousins, 1943, p. 13). By the end of World War II, Selecciones regularly sold twenty times its original estimate, with consumers buying over a million copies per month (Wharton, 1946). Its regional distribution made Selecciones the single most widely read magazine in Latin America. Back in the United States, as circulation numbers grew, so too did expectations that the international edition might bring readers further into the U.S. political and cultural orbit. Articles in the U.S. press lauded the little magazines as "ambassadors of U.S. culture" and, as decades rolled along, politicians noted the magazine's success as a cultural Cold Warrior.

Rather than pose itself as a direct emissary of U.S. culture, however, the magazine was careful to assert a "global" perspective. A closer look at the implications of this globality, the context of production, and stories of its consumption highlight that a critical component of the magazine's appeal and "success" was embedded in its stature as a periodical with an international following and worldly subject matter. In marketing itself as a "global" magazine, with "global" readership and "global" themes (while at the same time having clear U.S. origins), Reader's Digest actively transformed a rather old-fashioned, text-heavy, devoutly-conservative U.S. magazine into a narrator — and example — of modern globalization. In doing so, it also offered readers a portrait of what it could mean to be part of a "global middle class"; beyond merely idealizing the appeal of life in the United States, it asserted that a similar lifestyle and perspective were already available to its subscribers and readers. 
Scholars have recently paid greater attention to the importance of the notion of a global middle class for the $20^{\text {th }}$ century. As they have noted, in the second half of the century, the term middle class became both ubiquitous and vague. Certainly, part of the allure and function of the category is its flexibility: The middle class is at once an identity, a social group, a cultural signifier, an economic measure of income, and a politicized idea. Recent work on the topic has highlighted the trajectory of the term: U.S. Cold War policy often focused on bolstering a global middle class that might serve as a stabilizing (anti-revolutionary) economic — and political—force (Weinstein \& López, 2012; Parker \& Walker, 2013; Cosse, 2014a; Garguin \& Visacovsky, 2009). Such notions took hold in academic and political circles in the 1950s as the lynchpin of modernization theory. In the 1960s, anti-communist policies (the Alliance for Progress serves as one example) stipulated that modernization and, in particular, stimulation of the Latin American middle class, would undercut the appeal of leftist ideology. Long after the Cold War's close, development projects designed to encourage the growth of professional and educated sectors have remained key to U.S. deployment of "smart power." Most of these programs, as Barbara Weinstein and Ricardo López (2011, pp. 9-10) have pointed out, flattened the diversity of middle-class histories and experiences while also imposing a narrative of middle-class modernity that expanded outward from the U.S. and Europe, adopted by the Global South. Recovering a more diverse and complicated picture of middle-class identities and experiences has offered an important corrective to this hegemonic narrative.

However, placing the idea of the global middle class in historical context also raises the question of how it came to hold such a grip on the cultural imagination - not only as a category of analysis in political theory or in policies of development, but also as a part of everyday culture (Cosse, 2014b), a transnational identity that ordinary persons in many parts of the world could imagine themselves connected to. Media holds an important role in this construction: Its dual character as a narrator of historical processes and identities (its content) and as a consumer product that served as material evidence of the transnational connection it described, made it both an inciter of ideas, and a tangible form of "connection" to an imagined community. 
As the story of the launch of Selecciones serves to highlight, the U.S. magazine targeted Latin American professionals, viewing them as a consumer market as well as a politically-relevant group. Notably, this process began well before the Cold War and prior to the heyday of modernization theory. Yet, this approach did not occur within a vacuum. It arose as a component of a larger historical moment in which, on the one hand, U.S. media was emphasizing the significance of changes in media and communication technology in creating global ties, and, on the other hand, targeting "professional" and educated classes in Latin America figured as part of a broader cultural diplomatic (and commercial) strategy. The initiatives of the late Good Neighbor Policy saw the middle class as both critical political actors, as well as possible consumers for U.S. products.

From the moment of its launch, Reader's Digest became a key communicator of this ideal, conjuring a politically grounded portrait of what it might look like to be part of a global community. Often, and particularly in its first decades of international publication, the term middle class was not used explicitly: Instead, the magazine conjured the notion of a pro-capitalist, international contingent of like-minded persons with "similar occupational interests," and access to consumer goods, driven by a particular notion of "success" and positioned between lower and upper sectors. Above all, the imagined audience held a shared interest in "the world" and in generating connections with that world through modern consumer technologies. In this way, the story of Selecciones serves as an example of how $20^{\text {th }}$ — century transnational consumer media encouraged a complex imaginary-one that linked incipient ideas of what it could mean to be both global and middle class and set out to define those terms and implicate both in a political, and even sentimental, ideation of the world. ${ }^{2}$

This article takes a closer look at this story, using documents from the U.S. National Archives, the magazine, as well as a variety of other press sources, to untangle the connections between the first truly-global U.S. consumer magazine, the U.S. geopolitical project, and the evolution of the idea of a global middle class. First, it describes the relationship between the launch

2 On sentimentalism, see Klein (2003). 
of Reader's Digest's Latin American edition and U.S. cultural campaign's wartime initiatives; second, it examines the magazine's content, illustrating how the notion of a global connection was depicted in its pages. Taken together, these sections illustrate how the transnational mass media not only normalized the notion of a righteous middle class but also narrated that group's globality, seeking to implicate the reader in its scope. In the conclusion, it considers how local consumers might reinvent the global identity proposed on its pages.

\section{Early state collaboration}

Reader's Digest's 1940 announcement of its intention to launch a Latin American edition, and particularly its call for readers' personal contributions to the cause, came at a moment in which U.S. interest in Latin America was at an unprecedented high. Since 1933, the United States' Good Neighbor policy offered a significant change after decades of military and political intervention in the region, encouraging mutual lowering of tariffs on inter-American trade and formally renouncing military intervention. As conflicts in Europe heightened, the "friendly" initiative gained renewed importance. By late 1939, a call for hemispheric solidarity in Latin America held appeal for a broad contingent of Americans. Pro-Allied voices rallied around the need for improved hemispheric defense, warning that latent resentments against the United States in the region created an inroad for Axis infiltration. Maps and articles circulated in national media stipulating that, should a direct attack on the United States be made, it would likely come from within the region, with the Panama Canal as the most likely target. At the same time, business leaders recognized that the war served as an excellent opportunity to permanently evict European nations from their dominance in Latin American commerce. For many regular Americans-even those in favor of neutrality - the Christian rhetoric of the Good Neighbor policy, its calls for defense and its implied benign leadership of the region, appealed to a broader sense of American identity.

Government initiatives capitalized on this spirit and its grounding in defense and commercial interests. In 1938, the U.S. State Department had created the Division of Cultural Relations and elevated cultural and 
intellectual exchange as an important element to bolster the Good Neighbor policy's political tenor, and in 1940, Nelson A. Rockefeller became director of the newly created OCIAA, which gradually expanded into a fully-funded program that focused on cultural programming, commerce and defense. The campaign believed that Axis propaganda could be countered by U.S. consumer media and programming; it began to promote and produce radio, film and print material that encouraged Latin American audiences to imagine the region as united against the incursion of European war. Departments within the OCIAA also focused efforts on a wider range of projects that linked commercial and geopolitical goals: a blacklist of alleged Axis sympathizers in Latin America, an Inter-American bank for the management of loans, strategy to diminish the presence of German airlines, and strategic allocation of natural resources for the war. A multifaceted media program that deployed film, radio programming, advertising and print sources became a critical initial experiment in U.S. international propaganda.

The Reader's Digest's launch of Selecciones serviced these same goals; yet, its ties to the Good Neighbor policy and the Roosevelt administration were quite tenuous and at times, quite conflicted. Indeed, despite shared political and commercial interests in the region, the company and its editors were not adamant supporters of the Allied cause, or, for that matter, the OCIAA and Franklin Delano Roosevelt's recent applications of the Good Neighbor policy. In fact, by 1940 magazine-the most widely read in the United States - had positioned itself as a formidable and popular political adversary of the president (Heidenry, 1993; Sharp, 2000).

Reader's Digest grew in popularity during the 1920s as a "solution" to the vast quantity of media available in the United States during that decade-its editors ostensibly mined the numerous publications printed in the U.S. market, selecting only the most interesting or relevant articles, editing them into more concise renditions, and reprinting them in a monthly catalogue - a digest. In contrast to other magazines of the decade, Reader's Digest was also quite plain. It was small-half the size of most printed magazines; a table of contents served as the magazine's cover and, inside, twenty-five short articles ran in two columns of text with no photographs, 
advertisements, and only a rare single-tone illustration to break up the type. At the end of each article there were smaller segments with quotations, jokes, and entertaining anecdotes. With few original articles, low press costs, and a high subscription rate, the magazine offered a cheap, and seemingly complete, media alternative. ${ }^{3}$

Over the first decade of production and as domestic circulation numbers grew, the magazine's editorial perspective became more clearly defined as right of center, and in the wake of the New Deal, as a media that voiced clear opposition to the standing government. The editors often reprinted articles or commissioned original pieces that were anti-union, and on many occasions, anti-Semitic and in support of racist policies. While it created controversy among conservatives by openly discussing contraception and criticizing the tobacco industry, it also gave voice to racist, anti-Semitic and anti-Catholic opinions - an article in January 1926, for example, called the Klu Klux Klan the "Defender of Americanism" (Evans, 1926; Heidenry, 1993, p. 66); other pieces supported segregation or warned of Catholic and Jewish influence in U.S. culture. ${ }^{4}$ Throughout the 1930s, the magazine proffered a steady critique of Roosevelt's government, bolstered conservative candidates running for office, and at the end of the decade, generated support for isolationism.

The magazine particularly drew ire when it published untimely pieces on U.S. foreign policy. One famous example, published just weeks after the German invasion of Poland, was a commissioned piece by the former aviator Charles Lindbergh. "Aviation, Geography and Race" (Lindbergh, 1939) opened with the suggestion that the power of flight had altered man's relationship to the world-“"mountains, coastlines, great distances, ground fortifications, all those safeguards of past generations, lose their old sig-

3 The story of DeWitt Wallace and the founding of Reader's Digest has been retold many times, by the company itself, and in a number of books about the magazine. Heidenry (1993) remains one of the most detailed surveys of the company history; Joanne P. Sharp has done a particularly thorough job of examining the Cold War constructions of the U.S. magazine; and Christian Klein's chapter on the magazine has also properly located the U.S. magazine's construction of sentimentality as a key component of its Cold War imagination (see Klein, 2003; Bainbridge, 1946; Garlin, 1943; Schreiner, 1977; Wood, 1967; Heidenry, 1993; Sharp, 2000).

4 Heidenry (1993) provides detail of these examples. 
nificance as man takes to his wings"-and concluded that the technology was unsafe in the hands of non-white races: "It is time to turn from our quarrels and to build our White ramparts again [... I I is our turn to guard our heritage from Mongol and Persian and Moor, before we become engulfed in a limitless foreign sea” (Lindbergh, 1939, p. 64). A second article to draw controversy, "Our Deep Dark Secrets in Latin America," written by Republican Senator Hugh Butler and published in the November 1943 issue, directly targeted the OCIAA and the government's Latin American outreach, exaggerating its expenditures and calling it "a wasteful and massive Work's Progress Administration (WPA) for Latin America" ("Retorts 'Don' Wallace," 1943).

On these and other occasions, supporters of the president and his policies rallied against the magazine. Pro-Allied outlets and voices in the black press also called out the publication as a forum for fascism ("Reader's Digest is no," 1944, p. 1; Gladstone, 1944); others publicly decried the Reader's Digest's anti-Semitic and isolationist editorial choices, and E. B. White (1935) mocked the magazine's tendency to turn complex problems into easily-resolved conflicts that reaffirmed a conservative moral lens. In the fallout of the 1943 article, Vice President Henry Wallace issued a statement apologizing to Latin Americans for "the shocking slur made against them" ("Buying Good Neighbors," 1943, p. A2) and Democratic Senator Joseph Guffey lambasted Reader's Digest on the Senate floor as

\begin{abstract}
a power-crazed publisher [...] willing to torpedo the solidarity of the Western Hemisphere and besmirch the leaders of the Western republics if thereby he can contribute to the defeat of President Roosevelt's magnificent administration in the forthcoming national elections. (Guffey, as cited in Paul, 1977, p. 38)
\end{abstract}

Given the public tenor of their relationship, Reader's Digest's decision to launch a Latin American edition in line with the Good Neighbor policy might seem unexpected. Yet, rather than undercut the path of the magazine as an agent of cultural diplomacy, such tensions serve to highlight the degree to which early U.S. cultural diplomacy often relied on-and even benefited from - private entities that were propelled by their own motivations - commercial, political, or otherwise, and who acted in concert with, 
but without complete subservience to, state messaging. The appearance of independence had strategic benefits: A degree of division between state initiatives and the consumer media that delivered its message supported the notion that international U.S. media functioned as a private consumer good, driven by the mass popularity of its content, rather than state interests. State policies, in turn, could generate the ideal conditions to launch a commercial project once considered economically unfeasible.

In the case of Reader's Digest, the Spanish Latin American edition came at the heels of a less-successful British edition, and, in the context of controversy, was poised to re-establish the magazine as a "patriotic" outfit. In the U.S. press, the staff spoke openly about the company's intentions to use their magazine to promote U.S. culture and defense interests abroad and billed it as an economic sacrifice undertaken for the sake of national defense. Recalling the initial "risk" of launching the Latin American edition, one staffer told Nation's Business, "if you wonder why a magazine willingly undertakes such a loss, I can only say that Mr. Dewitt Wallace regards the magazine more as a public institution dedicated to patriotic work than as a private property" (Wharton, 1946, p. 40). In early 1943, The Saturday Evening Post hailed Selecciones as a cultural ambassador; three years later, as the company expanded to new international audiences in the post-war context, Time nicknamed the Spanish-language version the "goodwill edition" (Cousins, 1943, p. 12).

Even more than the positive press they received for the project, the company benefited from a number of tax exemptions and incentives that envisioned the magazine as a part of cultural diplomacy. In 1940, after the Lindbergh piece riled critics—but before Rockefeller's OCIAA was in full working order-the business manager for Reader's Digest, Al Cole, met with representatives of the U.S. State Department to discuss the possibility of a Latin American edition (Wharton, 1946, p. 40). The meeting jumpstarted the launch of the new edition: The U.S. Department of the Treasury would offer Wallace a tax exemption for the production costs on their Latin American edition, and by opening up the magazine to U.S. advertisers, would also indirectly receive state assistance. 
Over the following years, ties to the nascent cultural program bulwarked the commercial outlook of the magazine's already successful model. A few months after the launch of Selecciones, and prior to Reader's Digest's next venture - a Portuguese edition for Brazil—the OCIAA coordinated an advertising campaign that incentivized U.S. corporations and agencies to place ads (and thus provided funding) to pro-Allied media in the region. A memo written to corporations noted that the exemptions were so extensive that companies that did not expect to extract revenue from their advertising campaigns "would be at a level where $80 \%$ or more would be paid by government." The memo concluded that, "In a sense, government would be paying for this advertising indirectly" (Memorandum, 1940, p. 2). The advertisers (many of whom were not exporting due to wartime limitations) were asked to use the advertising space to promote hemispheric unity and the Good Neighbor Policy in their content (Export Advertisers Group, 1941). It was a model for funding that would continue in the post-war era, when geopolitical concerns rotated eastward and messaging transitioned from Anti-Axis to anti-Communist, and government agencies continued to enable the Reader's Digest's global expansion.

Although at first Reader's Digest and the government offices operated separately, the new budget and staff extended to the OCIAA gave way to more collaboration. As the OCIAA's program took shape, Reader's Digest began to request material from the office. Staffer George Kent noted the interest of government "in seeing that the U.S. point of view is properly presented" as well as the editorial staff's need for more material: "we have a tie up that would be extremely profitable" (Kent, 1941, p. 2). The OCIAA began to feed the editorial board stories for reprint and in a following memo, suggested that the company allow them to provide ten percent of their article feed (Frantz, 1942a, 1942b, and 1942c). The two parties agreed to a form of collaboration: The Office of Press and Publications began to regularly send articles and article ideas to Reader's Digest, which would edit and adapt them to fit the publication's tone. The arrangement highlighted an important overlap: Although the magazine's international editions did not become a formal state project, the company remained open to receiving and curtailing content to align with state interests and reflected their propaganda goals. 
Although editorial control remained in the hands of Reader's Digest, the company's ideological objectives in the international field made room for closer ties. The editors' own framework and priorities, while at odds with the administration in terms of domestic policy, shared key points of interest. Barclay Acheson (the brother of the magazine's co-founder, Lila Wallace) took the helm of the company's international editions at its launch. His own experience as a Presbyterian minister, missionary, and the former Overseas Director of the Near East Relief Foundation (NER) informed his perspective. At NER, Acheson hardened his anti-communist sentiments (a perspective he shared with his brother-in-law). He likewise developed a strong personal conviction of what it meant to lead a private Christian organization in international outreach; reflecting on the experience, he noted that the work in the field instilled in him the importance of teaching morality and emphasized his hard-earned lessons of the need to adapt a program to the local context (Rodogno, 2014, p. 48). Acheson's priorities, reflected in his days at the NER, remained focused on the power of mass education and moral uplift-a kind of work that required the mobilization of a humanitarian class (Rodogno, 2014, p. 48; Watenpaugh, 2015, pp. 183-187).

In 1947, Selecciones was enjoying unforeseen success in Latin America, and thus Acheson sought government support for his next initiative: expanding the reach of the Digest into Europe, Asia, and behind the Iron Curtain. There, Acheson (1947, December 10) suggested, Reader's Digest would be poised to invigorate a sense of identification with a much broader, global consumer base. It was a task that he said could only be completed by private industry: The lessons from Latin America had made it clear that consumers placed value on the idea that the magazine represented "unsubsidized, free media, untouched by the taint of organized national propaganda, purchased freely and voluntarily by the foreign reader" (Acheson, 1947, December 10, p. 1). The "effectiveness" of Selecciones' message in Latin America, he reminded government, was dependent on the idea that it was not a government production. Should such a relationship be openly admitted, he said "the State Department will subject itself to vicious attack by foreign opponents as misleading the foreign public by engaging in paid propaganda falsely presented" (Acheson, 1947, December 10, p. 1). Beyond the potential of 
being discredited, "voluntary purchase" was "the key to any educational effectiveness American magazines may have" (Acheson, 1947, December 10, pp. 1-2). It was, however, more important for the magazine to convey this message than to refuse government funding. Acheson encouraged the government to continue to find ways to fund the magazine's ongoing global expansion while reiterating that they must not "give opponents of American policy a ready-made proof of the designs of the U.S. government for 'cultural imperialism' all over the world" (Acheson, 1947, December 10, p. 2). Such correspondence underlines the magazine's geopolitical ambition and the ties between private industry and government. At the same time, however, it elucidates the degree to which the editors viewed their magazine as a missionary consumer product, one designed to "educate" its readership and spread its U.S.-based construction of "global" modernity.

\section{Latin America and the idea of the global middle class}

The initial announcement of Selecciones in the U.S. press - the call for U.S. Reader's Digest subscribers to donate money for their magazine to reach Latin America's consumers-offers an opportunity to consider the parallel markets that the editors had begun to map out, even before launching their international project. U.S. subscribers, the ad supposed, were persons willing and able to engage in a project of international uplift, donating a small sum to an international peer group — persons that were "similar to them," sharing education and professional status - who were not able to afford their own full-priced subscription. The editors thus also referenced an imagined Latin American market-professionals, students and "prominent women" that, at least in this description, required or sought U.S. collaboration.

This idea that there might exist two parallel audiences for these types of exchange was not an invention of Reader's Digest, but part of a broader public discourse that had begun to place importance on a vaguely defined Latin American middle sector. In the late 1930s, incipient wartime media had begun to suggest that personal connections among the world's peoples might figure as a component of international relations, and that such con- 
nections would transpire among global peers. This imaginary link was particularly visible in public responses to the Good Neighbor policy, which became an important element in popular U.S. culture from 1939 to roughly 1942. During this brief period, as I have noted elsewhere, ordinary U.S. Americans saw a proliferation of references to Latin America and the Good Neighbor policy in everyday life and found many ways to "participate" in forging inter-American relations. Local papers invited housewives to cook a Pan American dinner at night, Latin American-themed fashions became available in stores and the Samba popularized on the radio; longer-term proponents of Pan Americanism noted an unprecedented demand in Spanish classes and participation in Pan American themed clubs (Ubelaker-Andrade, 2015). The sudden — and fleeting — interest in regional relations was often framed as a way for ordinary Americans to engage in international relations, exhibiting at home the morality of U.S. power. The media encouraged readers to see the Good Neighbor policy as an opportunity for collaborative, moral international relations that required action on the part of everyday Americans. While Reader's Digest suggested that its subscribers help launch their international edition, Ladies Home Journal sold Hemispheric Solidarity pins; trade magazines like The Pan American interpreted the sudden interest, noting that the Good Neighbor Policy was a "Christian doctrine that all of us should be good neighbors, doing unto others as we would be done by" ("Good Neighbors," 1941, p. 14). In these rather romanticized interpretations, a new era of inter-American relations became reconfigured as a moral model for U.S. power: Small acts, like purchasing Latin American products, learning about the peoples of Latin America, were portrayed and performed as a part of a broader action in support of national defense and U.S. global moral leadership.

As scholars have shown, in the United States and beyond its borders, justifications of U.S. intervention were also often narrated and depicted in moral terms, often in a colonial paradigm of "white man's burden," in which American leadership and forces were required to impose order and civilize. By contrast, the explicitly-anti-colonialist Good Neighbor policy was commonly narrated as the meeting of (white) educated professionals, that, while still unequal, functioned as international peers. Rather than 
denominate them as a "middle class," these Latin American "neighbors" often bore traits of modernity, often appeared to be white, and were commonly described by their occupational status as educated or professional, or characterized as neither wealthy nor poor. For example, the Walt Disney/OCIAA collaborative film, Saludos Amigos (1942), foregrounded real footage of modern Latin American cities and fashionable residents; That Night in Rio (1942), which, while nonetheless playing up Latin tropes, portrayed Latin Americans as a whitened, elegant audience; Vogue magazine, in an article on what to pack for a Pan American journey, encouraged readers to dress casually but elegantly when visiting modern metropolises of the Southern Cone, to be on par with their cosmopolitan hosts ("Packing for," 1942, p. 68). Pan Americanist magazines provided further fodder for the imagination that delved more deeply into the "modern" Latin America of the Good Neighbor era. In 1943, The Pan American offered a discussion of Latin America's "New Woman," disparaging the stereotype of the señorita: "the old days of fanning one's brow on a flowered balcony are as dead and gone as the Puritan costumes...” (Mendoza, 1943, p. 40) and replacing it with new ones: The peasant woman was "slow to form an opinion, as is her husband," the "working class" woman "conformed" to leftist politics, and the upper class woman was too influenced by "her husband, father or brother" (Mendoza, 1943, p. 40). The middle-class woman, was "independently-minded, university-educated and eager for a new social role" (Mendoza, 1943, p. 40). Similar examples often more vaguely defined the protagonists of Latin American intercultural relations by their professional background, as well as an outlook on the world.

Reader's Digest's depictions of its targeted international audience fit into this broader cultural discourse, but, unlike much of the U.S.-oriented Pan American media, it was directed at Latin American audiences, and envisioned as a tool of propaganda. Unsurprisingly, given these designs, the launch of Selecciones del Reader's Digest was not positioned as a magazine charitably provided by U.S. counterparts, nor as a "goodwill" or diplomacy-driven project. Rather, it was first introduced as an example of modernity: an imported U.S. magazine edited for Latin Americans and made affordable and possible by the advent of new media technologies. One an- 
nouncement told readers that previous efforts to publish a Reader's Digest for Latin America were stalled by production costs, but

now, new instant dry ink permits a machine to work at a high speed and simultaneously print various colors on satin paper. For these new presses it is easy to complete issue of Selecciones, cut it and bind it in a few seconds. ("La historia de," 1940, p. 82)

"Latin American neighbors," the editors added, were "sure to enjoy" the magazine because "in sharing the same hemisphere, they also shared many problems and interests, as well as a similar character and political philosophy" ("La historia de," 1940 p. 82). In descriptions like these, Selecciones, which, like its U.S. counterpart, was a simplistic, low-tech, stapled text magazine without photographs, was reconstrued as modern, and its international readership was portrayed as sharing a "certain character" with the magazine's existing audience in the United States.

It was not long before editors proposed that these two qualities - the magazine's capacity to travel and the "shared character"' of its readershipmade it a novel way for ordinary people to "connect" to the world. In a promotional essay included in the December 1942 issue, Brazilian artist María Martins told readers that Selecciones was where she, then married to the Brazilian ambassador in Washington, connected to "events outside of the circles in which I move" and learned of "independent spirited men and women who worked consistently to solve the problems that our societies face" (Martins, 1942, December, back cover). In the July 1943 issue, Ana de Martínez-Guerrero, the Argentine delegate and president of the Pan American Inter-American Commission on Women, compared Selecciones to an airplane, emphasizing that readers who could not afford a plane ticket could have a modern relationship with "the world" by reading (de Martínez-Guerrero, 1943, July, back cover). Selecciones, de Martínez-Guerrero proposed, allowed the imagination to travel the world even when the body could not.

The trope of the magazine as a portal of global connection was often repeated in its early promotional material. In a testimonial printed in the July 1944 issue, an American missionary to China extolled the value of Reader's 
Digest in connecting "free peoples" with an anecdote: He recalled entering a barber shop in the northern mountains of China only to overhear a "cosmopolitan" conversation taking place-curious, he discovered the source of the storyteller's wisdom: a hidden collection of recent issues of Reader's Digest. In the May 1943 issue, an endorsement from Roberto Unanue, an Argentine journalist, former editor of La Nación, and an OCIAA collaborator, described Reader's Digest as a tool for professionals in Buenos Aires. On his first day of work at La Nación, he brought along a Reader's Digest (then in English) and told the editor that the magazine kept him "informed of a thousand things that happen in the world and never make it to the national media" (Unanue, 1943, back cover). In yet another endorsement, medical doctor Julio Cantala said the magazine was "a prescription for persons with signs of depression or anxiety" because it brought them to "new horizons and knowledge" (Cantala, 1941, back cover). In the July 1943 issue, a second OCIAA collaborator, Alejandro Sux, recounted an evening in 1911 when he and Rubén Darío went to visit the poet Leopoldo Lugones in Paris. Lugones complained that he needed five polyglot secretaries to keep up with the world:

After I read the first issue of Selecciones del Reader's Digest, I exclaimed, I have more luck than Lugones and Darío together, I have twenty secretaries... If Selecciones is of such value for a professional like myself, who takes hours of work to inform himself of what is happening in the world, even better for the millions of people who only have a few moments to read!" (Sux, 1943, back cover)

Professionals and ordinary people - in locations as disparate as China, Paris and Argentina—could rely on Reader's Digest to acquire a pithy, visceral understanding of "the world."

Advertisements reinforced the broader notion that U.S. media and the Good Neighbor era were generating a new connection among an international community of peers. As the only illustrations printed in the magazine, they also served to bring many of the magazine's messages to life. In a 1941 issue of Selecciones, an advertisement from the United States Rubber Export Company, for example, provided a rather literal imagination of the U.S. policy. In the ad, a white, suited businessman, appearing to stand 
on the Florida Coast, waves his hat to crowd of persons in South America. Visible on the other side of the Caribbean are a slender white young woman with flowers, a similarly-suited man with briefcase, a doctor, a basketball player, and a man in overalls - an all-white, mostly (though not exclusively) "professional” image of South American "friends" (United States Rubber Export Company, 1941, p. 121).

Other ads underlined the notion that persons around the world could use modern global media and their imaginations to "connect" through their respective living rooms. A 1941 ad for the Radio Corporation of America depicted a blonde woman seated in her living room-a globe turned to the western hemisphere and a small radio on a table beside her: The RCA radio put "five continents at arm's reach" (RCA Victor, 1941, p. 139). A 1943 ad from Zenith again drew a contrast between a world at war and the comfortable quiet of a living room: "Far from the tragic scene of a world at war, reclined in the pleasure of your home, you can rest and be at ease beside a Zenith" (Zenith, 1943, p. 149). Collectively, the ads reinforced the coherent message that international media technologies could provide a space for a certain class of interested persons, the world over, to bypass national boundaries and local conditions and "connect."

At the dawn of the Cold War, the magazine itself defined this role more clearly. As Reader's Digest expanded to more global locations and published in more languages, the magazine's own global trajectory became its primary selling point. One advertisement called the magazine "a step towards universal brotherhood": It included endorsements from a student in Chile, a professor in Stockholm (who cited it as a source of his education), and a Brazilian magistrate. The magistrate lauded that the magazine "teaches us" to "lift our eyes and take them around the world" ("Otro paso," 1945, October, back cover). The ad conjured a class of persons around the world who shared essential qualities and a vague sense of geopolitical purpose: "As war retreats from the devastated continents of the world, we need, in every country, minds that can comprehend and hearts that can feel" "Otro paso," October, 1945, back cover). Here, readers were not only defined by their work (though their professional occupations were often noted), but 
by other vague traits: sentimentality, reason, curiosity, and an intellectual interest in the world outside their immediate reality. In this light, Selecciones was not a universal media in that it was not for everyone (its readership was portrayed to be people of a particular heart and mind) — but it was global - both in terms of the scope of its information and in its capacity to fraternally connect readers across space.

The ads insisted not merely that Reader's Digest forged a connection between Latin America and the United States, but rather, that the magazine served as a gateway to globality, and this notion was reinforced by its content. Selecciones offered what appeared to be a diverse scope of articles that jumped from subject to subject and setting to setting. A 1956 issue began with an article on "Italians and the Art of Living," followed by, "What Eisenhower Doesn't Like," (a profile of the president); "Why I Can Never Remember a Name," (a comic's take on a common mishap); "Muñoz Marin, Leader and Poet," (a flattering profile on the governor of Puerto Rico); "The Great Australian North," (depicted as a "modern land of adventure"); "Airplane Traffic on the Skyways" (how air traffic controlled managed global flight patterns); and "What I Saw in Red China" (a first-person account that described the Chinese as "losing all signs of their culture" and becoming a subordinate replica of Soviet Russia (Table of Contents, 1956, November, front cover); the final article was a longer book excerpt from Dr. John Schindler's "How to Live 365 Days of the Year," which offered advice on how to fully enjoy one's life, like "learn to enjoy your work" (those who do not enjoy their work, it warned, were likely to suffer an illness caused by their emotions), "feel sympathy for others," and "make happiness a habit" (Schindler, 1956, p. 179). Most issues, like this one, included several articles set in countries around the world, at least one that provided testimony of destructive path of Soviet Russia, at least one profile of a Latin American, two articles on scientific advancements, an inspirational story of personal improvement, and at least one piece that offered direct advice on how readers might improve their happiness and individual outlook on life. Taken together, the articles portrayed a "world" that was deeply anti-communist and was propelled into "progress" by scientific novelty. It was consistently laudatory of a particular kind of protagonist: one who found or searched 
for economic success through hard work, ingenuity, or innovation; sought out understanding of the world; engaged in a paternalistic civilizing or uplift of the poor, children, or "savage" persons; and found "pleasure" in personal improvement and domestic happiness.

Although "the middle class" was occasionally referenced explicitly as a globalizing phenomenon, more often, it was constructed and alluded to in descriptive terms. The morality of a global "professional" sector was often vividly illustrated in tropes and first-person narratives. Certain characteristics - moderation, charity, ingenuity, paternalism, personal bettermentdrove the storylines of "professionals" in disparate locations. In the 1940s, many such examples were simple stories of paternalistic uplift or creative success (a missionary in China teaches a village to read, a Peruvian hacienda owner teaches a "savage" the value of hard work, a doctor in a small town in the United States discovers the power of fluoride). By the 1950s, however, stories connected the global middle class's underlying morality, charity, and paternalism with the Cold War: They were the characteristics oppressed under communism, and, at the same time, the most effective tool to combat it. "Jimmy Yen y la Cruzada del Pueblo," a story from a September 1955 issue, for example, told the tale of the doctor turned humanitarian teacher who taught literacy in the Chinese-and then Filipino-countryside, "making sure their bowls of rice were full and their humanity respected" ("Jimmy Yen," 1955, p. 186). Yen's literacy campaign foregrounded the abolishment of poverty and access to literacy as an anti-communist project, and celebrated the devotion and participation of teachers, professors, scientists, and educated people from around the world.

Articles in September 1956 and 1957 reiterated the same moral landscape: both issues featuring stories on Dr. Lawrence Jones, a member of the U.S. black middle class engaging in humanitarian uplift in the United States (Jones, 1957; "El maestro," 1956). In the 1957 story, Jones told readers that he was of humble roots, but with dedication and hard work and the support of his mother, he earned a degree; after college, he received a number of "tempting job opportunities" but saw the pursuit of individual wealth as a "waste" of his education, instead opting to uplift those with less than him 
(Jones, 1957, p. 105). After seeing the "ignorance" of poverty firsthand, Jones built a school in Mississippi to "teach these people to not waste the little they had" (Jones, 1957, p. 106). As a paternalistic figure taking action to uplift an "uneducated" lower class, Jones entered into the intentionally diverse pantheon of Reader's Digest's moral protagonists.

Articles that offered advice rather than a story reinforced the idea that these moral qualities were not exceptional, but rather were obtainable for the magazine's readership. An article from the February 1952 issue, "Decir que sí es dar más," instructed readers that the best gifts were not expensive consumer goods but are those that touch the heart-offering babysitting services to a sister, reading aloud to an elderly neighbor, donating to the poor, teaching the illiterate, were gifts more valuable than anything bought in a store. The magazine invited readers to realize that, through their own participation in charity, readers could share in the moral qualities extolled in the magazine's stories: "every day we have opportunities to be give part of ourselves to those who need our help." ("Decir que sí es," 1952, p. 85). Too, they could reinforce their sense of belonging to a class of persons, here defined not merely by their profession, education, and social position, but also by their sentimental engagement with others.

Self-help articles also emphasized the importance of imagination and supposed a desire for "professional success" among its readership. Imagination, editors asserted, would enable persons everywhere to sympathize with others, advance professionally, sympathize with others elsewhere in the world, and employ the qualities of innovation and charity. In "Una gimnasia de la imaginación," Giles (1942) explained to readers that it was not necessary to be a creative person or inventor to see the world from the perspective of other people: "try it and you will perfect your ability to imagine and sympathize" (Giles, 1942, p. 7), it advised. Mursell's (1943) "Administre su imaginación" compelled the reader to broaden their understanding of the world in order to excel professionally. "La imaginación nace en casa" (1951) described how different professionals—a business owner, an engineer, and a scientist—used their imagination to innovate their field and beseeched families to teach the skill of imagination to their children, 
preparing them for success and also livening the "monotonous routines" of their daily lives. With imagination, the ordinary home was "an airport where new ideas land and materialize in the form of new music, as fashion, as a new car, a hobby" ("La imaginación nace," 1951, p. 56). In these articles, as elsewhere, the emerging portrait of a global community was paradoxically both implicit and specific: The readers were encouraged to see themselves as moral, as sharing professional (classed) ambitions, and mutually connected by modern novelties and consumer culture. At the same time, belonging to such a group was obtainable, inclusive, and possible.

\section{Conclusions and considerations of Reader's Digest as a local phenomenon}

While a deeper examination of the hybrid and transnational identities that formulated around Selecciones is out of the scope of this article (though I have examined the topic with greater attention elsewhere), it is important to consider the ways in which a transnational media, like Selecciones, can be ascribed new meaning when it is taken up by local consumers, in context and on the ground (Ubelaker-Andrade, 2014). As new work on the history of the middle class has shown, we must be careful not to replicate the hegemonic construct of a singular middle class by assuming that those identities, or the narration of a global middle class as part of a widely-popular consumer good, equate a uniformity of experiences or identities. This is all the more true for Reader's Digest, which regularly used its international editions' consumer success as evidence of its Cold War influence.

By the same token, it would be a grave error to imply that Selecciones's arrival in Latin America somehow introduced or single-handedly narrated globality or middle-class identity to its readership. Entirely to the contrary, it was likely the very long and entrenched history of global media in the region, and the hybrid and constantly-evolving local notions of modernity and middle-class identity (rather than their introduction) that made Reader's Digest an attractive addition to local reading options, in the first place. In Argentina, the country that quickly became the magazine's most avid audience of subscribers, this appears particularly relevant. While media at mid-century may have been illustrating a renewed celebration of the 
global, in Argentina and across Latin America, the allure of international connectivity was also far from new. For decades, the promise of a type of "direct" connection to news from abroad became a critical component of various waves of globalization and modernization in the region, and local presses often emphasized their own globality as a marketing point to local readers (Caimari, 2016).

Moreover, and as has been well documented by many scholars, national magazine and newspaper production in Argentina proliferated in the first decades of the $20^{\text {th }}$ century-the kiosk of the 1930s offered a parade of reading options for a vast readership. In Buenos Aires, the growth of an educated professional sector, and the expansion of modern ways of living: The single-family home, new neighborhoods, and community life expanded a broader sense of social mobility. In Argentina, as elsewhere, Reader's Digest's international editions entered in social landscapes in which complex local processes of modernization, globalization and class identities were already underway. Its insistence that readers existed in a world in which a broad contingent of similar persons employed a sense of moderation, engaged in paternalistic uplift, and could, through media, join a broad global middle class, thus interplayed against local notions and experiences of class, as well as local political discourses.

The excavation of these local ideas is critical to a historicized understanding of the global middle class; however, as this article suggests, it is also enlightening to examine how, under what conditions, and in what forms, the hegemonic notion of a pro-capitalist middle class globalized and circulated among ordinary persons. This article suggests that U.S. efforts to mobilize the professional classes as geopolitical actors predated the Cold War. In the case of Reader's Digest, the purpose of propaganda was not merely to reach, describe and "educate" middle class consumers but to initiate and insist among those readers that media and information served as a type of portal of connection, a way of constituting a global identity among them. In this sense, the export of U.S. media was not merely a method of outreach - it became part of its message: On its pages, the magazine actively described an imaginary class of consumers around the world who shared a similar outlook, as well as a common source of information. 


\section{References}

Export Advertisers Group. (1941, September 25). Meeting minutes. U.S. National Archives at College Park, College Park, MD.

Acheson, B. (1947, December 10). [Letter to Howland H Sargent C, Tyler Wood, State Department, Copied to Norman Armour]. Record Group 59. (General Records of the Department of State. International Information Administration Private Enterprise Cooperation Staff (IIA/ICO) Subject Files, 1941-1953. Reader's Digest). National Archives at College Park, College Park, MD.

Bainbridge, J. (1946). Little wonder or The Reader's Digest and how it grew. New York, NY: Reynal \& Hitchcock.

Butler, H. (1943, December). Our deep dark secrets in Latin America. Reader's Digest, 43, 21-25.

Buying good neighbors. (1943, November 28). The Hartford Courant, p. A2.

Caimari L. (2016). News from around the world: The newspapers of Buenos Aires in the age of the submarine cable, 1866-1900. HAHR, 96(4), 607-640. DOI: https://doi.org/10.1215/00182168-3677615

Cantala, J. (1941, December). Sedación Psíquica. Selecciones del Reader's Digest [Back cover].

Cosse, I. (2014a). Mafalda: Middle class, everyday life, and politics in Argentina 1964-1973. HAHR, 94(1), 35-75. DOI: https://doi. org/10.1215/00182168-2390604

Cosse, I. (2014b). Las clases mediasen la historia reciente latinoamericana. Contemporánea, 5(5), 13-19. Retrieved from http://www.geipar. udelar.edu.uy/index.php/2017/05/06/articulos-5/

Cousins, N. (1943, April). 1,200,000 ambassadors. The Saturday Review of Literature, pp. 12, 13, 14, 42, 43. 
Cramer, G., \& Prutsch, U. (2012). ¡Americas Unidas!: Nelson A. Rockefeller's Office of Inter-American Affairs (1940-46). Madrid, Spain: Iberoamericana Vervuert.

de Martinez Guerrero, A. (1943). Selecciones del Reader's Digest [Back cover].

Decir que sí es dar más. (1952, February). Selecciones del Reader's Digest, 85.

Evans, W. (1926, January). The Klan: Defender of Americanism. Reader's Digest, 583-584.

El maestro de los Pinares. (September, 1956) Selecciones del Reader's Digest, 113-121.

Frantz, H. (1942a, January 16). [Letter to A. L. Cole, General Manager, Reader's Digest]. RG 229. (Records of the Department of Press and Publications. General Records. (E-127). QN-RZ. Reader's Digest). National Archives at College Park, College Park, MD.

Frantz, H. (1942b, March 24). [Letter to DeWitt Wallace] Record Group 229. (Records of the Department of Press and Publications. General Records. (E-127). QN-RZ. Reader's Digest). National Archives at College Park, College Park, MD.

Frantz, H. (1942c, May 15). Memorandum: Materials for Reader's Digest. [Memorandom to Hall and Eichel]. RG 229. (Records of the Department of Press and Publications. General Records. (E-127) QN-RZ. Reader's Digest). National Archives at College Park, College Park, MD.

Garguin E., \& Visacovsky, S.E. (2009). Moralidades, economías e identidades de la clase media: estudios históricos y etnográficos. Buenos Aires, Argentina: EA.

Garlin, S. (1943). The truth about Reader's Digest. New York, NY: Forum Publishers. 
Giles, R. (1942, August). Gimnasia de la imaginación. Selecciones del Reader's Digest, 6-8.

Gladstone W. (1944, September). Reader's Digest loses partiality. The Atlanta Constitution, 10.

Good Neighbors. (1941). Pan American, 12, 14-15.

Hart, J. (2013). Empire of ideas: The origins of public diplomacy and the transformation of U.S. foreign policy. New York, NY: Oxford University Press.

Heidenry, J. (1993) Theirs was the kingdom: Lila and Dewitt Wallace and the story of Reader's Digest. New York, NY: W.W. Norton.

Jimmy Yen y la Cruzada del Pueblo. (1955, September). Selecciones del Reader's Digest, 105-109.

Jones, L. (1957, September). El mejor consejo que jamás oí. Selecciones del Reader's Digest, 105-107.

Kent, G. (1941 December 14). [Letter to Frantz]. Record Group 229. (Records of the Department of Press and Publications, General Records, E-127, QN-RZ) National Archives at College Park, College Park, MD.

Klein, C. (2003). Cold War orientalism: Asia in the middlebrow imagination. Berkeley, CA: University of California Press.

La historia de The Reader's Digest y de Selecciones. (1941, October). Selecciones del Reader's Digest, 82-83.

La imaginación nace en casa. (1951, September). Selecciones del Reader's Digest, 54-56.

Lindbergh, C. (1939, November). Aviation, geography and race. Reader's Digest, 64-67. 
Martins, M. (1942, December). Mi refugio espiritual. Selecciones del Reader's Digest [Back cover].

Memorandum. (1940, December 14). [Memorandum]. Record Group 229. (Records of the Department of Press and Publications, General Records. E-127, QN-RZ, Reader's Digest). National Archives at College Park. College Park, MD.

Mendoza, A. (1943, January). The new Latin woman. The Pan American, 39-40.

Mursell, J. L. (October 1943) “Administre su imaginación.” Selecciones del Reader's Digest, 21-23.

Otro paso hacia la fraternidad universal. (1945, October) Selecciones del Reader's Digest, [Back cover].

Packing for Pan America. (1942, January). Vogue, 68-69.

Parker, D. S., \& Walker, L. E. (2013). Latin America's middle class: Unsettled debates and new histories. New York, NY: Rowman and Littlefield.

Paul, J. F. (1977). Senator Hugh Butler and aid to Latin America, 19431944. South Dakota History, 8(1), 35-45. Retrieved from https: // www.sdhspress.com/journal/south-dakota-history-8-1/senatorhugh-butler-and-aid-to-latin-america-1943-1944/vol-08-no-1senator-hugh-butler-and-aid-to-latin-america-1943-1944.pdf

RCA Victor. (1942, May). [Advertisement]. Selecciones del Reader's Digest, 139.

Reader's Digest is no Digest. (1944, September). The Baltimore Afro-American, 1.

Reader's Digest: Spanish for Latin America. (1940 July). San Francisco Chronicle, 9.

Retorts 'Don' Wallace is wrong by billions. (1943, November). The Atlantic Constitution, 6B. 
Rodogno, D. (2014). Beyond relief: A sketch of the Near East relief's humanitarian operations, 1918-1929. Monde(s), 6(2), 45-64. DOI: https://doi.org/10.3917/mond.142.0045

Schindler, J. (1956, February). Para vivir 365 días del año. Selecciones del Reader's Digest, 171-190.

Schreiner, S. A. (1977). The condensed world of the Reader's Digest. New York, NY: Stein \& Day.

Sets circulation record: Reader's Digest claims world mark of 4,100,000 copies. (1940, December 26). The New York Times, 17.

Sharp, J. P. (2000). Condensing the Cold War: Reader's Digest and American identity. Minneapolis, MN: University of Minnesota Press.

Sux, A. (1943, February). ¡Aquí están tus secretarios! Selecciones del Reader's Digest [Back cover].

Table of Contents. (November, 1956). Selecciones del Reader's Digest [Front cover].

Ubelaker-Andrade, L. (2014). La revista más leída del mundo: Selecciones del Reader's Digest y culturas de la clase media: 1940-1960. Contemporánea, 5, 21-41. Retrieved from http://www.geipar.udelar. edu.uy/index.php/2017/05/06/lisa-ubelaker-andrade/

Ubelaker-Andrade L. (2015). Bazar panamericano: Cultura de consumo y participación popular en el poder estadounidense (1939-1942). Avances del Cesor, 12(13), 181-203. Retrieved from http://web2. rosario-conicet.gov.ar/ojs/index.php/AvancesCesor/index

Unanue, R. I. (1943, May). Doce lápices y una revista. Selecciones del Reader's Digest [Back cover]. 
United States Rubber Export Company. (1941, January). [Advertisement]. Selecciones del Reader's Digest, 121.

Watenpaugh, D. (2015). Bread from Stones: The Middle East and the Making of Modern Humanitarianism. Berkeley, CA: University of California Press.

Weinstein, B., \& López, A. R. (2012). The making of the middle class: Toward a transnational history. Durham, NC: Duke University Press.

Wharton, D. (1946, October). The world is its newsstand. Nation's Business, 34(10), 40-41.

White, E. B. (1935, November 16). Irtnog. The New Yorker, 17.

Wood, J. P. (1967). Of lasting Interest: The story of Reader's Digest. New York, NY: Doubleday.

Zenith. (1943, October). [Advertisement]. Selecciones del Reader's Digest, 14. 